\title{
On Design Optimization of a Composite Impact Attenuator Under Dynamic Axial Crushing
}

Motorization brings two significant challenges to the modern society. Firstly, road and vehicle safety becomes increasingly important, which has notably heightened legislative requirements by introducing more effective protective systems to the vehicle. Secondly, there is an ever-growing concern in environment and sustainability, which largely push up the lightweight standards to reduce fuel consumption. For these reasons, the automotive industry has devoted a substantial effort to deliver more crashworthy vehicles for addressing these two competing issues simultaneously. Over the past two decades design optimization has been developed as a powerful tool to seek the highest possible crashworthiness and lightest possible structure for various vehicles, therefore becoming an important topic of research. In crashworthiness optimization, direct coupling method may be inefficient since iterative non-linear FEA during optimization usually require huge computational efforts and take the high risk of premature simulation failure prior to a proper convergence. As a result, surrogate models (or metamodels) are more often used as an alternative for formulating the design criteria in terms of an explicit function of design variables in advance of optimization, which has proven an effective and sometimes a unique approach. The idea of surrogate modeling is to construct an approximate function based on a series of sampling evaluations, in which design space is typically sampled using the design of experiment methods. Then, the FEA is performed at these sample points to establish surrogate models with a certain confidence of approximation for crashworthiness optimization.

This paper provides the results obtained from an optimization procedure on a composite impact attenuator, under dynamic axial crushing, using two different metamodels, such as Radial Basis Function and Kriging. In particular the sizing optimization for some geometric parameters was solved combining the commercial solver LS-DYNA with the optimizer LSOPT. In order to measure the fitness of results and do a comparison between different surrogates, global error parameters were used, such as root mean squared error, maximum residual error and coefficient of determination.

Keywords: crashworthiness, optimization, surrogate model, axial crushing, LS-OPT, LS-DYNA.

\section{INTRODUCTION}

Motorization brings two significant challenges to the modern society. Firstly, road and vehicle safety becomes increasingly important, which has notably heightened legislative requirements by introducing more effective protective systems to the vehicle. Secondly, there is an ever-growing concern in environment and sustainability, which largely push up the lightweight standards to reduce fuel consumption. For these reasons, the automotive industry has devoted a substantial effort

Received: February 2017, Accepted: March 2017

Correspondence to: Dr Simonetta Boria

Mathematics division, University of Camerino

Madonna delle carceri 9, 62032 Camerino, Italy

simonetta.boria@unicam.it

doi:10.5937/fmet1703435B

(C) Faculty of Mechanical Engineering, Belgrade. All rights reserved to deliver more crashworthy vehicles for addressing these two competing issues simultaneously. Thin-walled structures are of great importance in automotive crashworthiness design, because of their high crash energy absorption capability and their potential for light weighting. To identify the best compromise between these two requirements, numerical simulation and optimization is needed [1-6]. Due to the numerical noise and physical bifurcation in crash response, gradient based optimization algorithms cannot be used directly here. On the other hand, because of high computational cost for crash simulation, it is improper to apply evolutionary algorithms directly. To overcome the above problems, surrogate models are generally built to capture the crash response $[7,8]$. The idea of surrogate modeling is to construct an approximate function based on a series of sampling evaluations, in which design 
space is typically sampled using the design of experiment methods [9]. Then, the FEA is performed at these sample points to establish surrogate models with a certain confidence of approximation for crashworthiness optimization.

This paper provides the results obtained from an optimization procedure on a composite impact attenuator, under dynamic axial crushing, using two different metamodels, such as Radial Basis Function (RBF) and Kriging. In particular the sizing optimization for some geometric parameters was solved combining the commercial solver LS-DYNA with the optimizer LS-OPT. In order to measure the fitness of results and do a comparison between different surrogates, global error parameters were used, such as root mean squared error, maximum residual error and coefficient of determination.

\section{SURROGATE MODELING}

In crashworthiness optimization, direct coupling method may be inefficient and sometimes impossible since iterative non-linear FEA during optimization usually require enormous computational efforts and take the high risk of premature simulation failure prior to a proper convergence. As a result, surrogate models or metamodels are more often used as an alternative for formulating the design criteria in terms of an explicit function of design variables in advance of optimization, which has proven an effective and sometimes a unique approach [10].

In this study comparative analysis of Radial Basis Function and Kriging metamodels were carried out using Latin Hypercube design of experiment; approximated functions were created using ten simulation points and fifteen iterations with sequential domain reduction strategy. Below it is presented a brief description of such models.

\subsection{Radial basis function model}

Radial basis function model was developed for scattered multivariate data interpolation by using a series of basis functions that are symmetric and centred at each sampling point. Radial basis functions are typically formulated using the Hardy's formula [11]:

$$
\hat{y}(x)=\sum_{j=1}^{m} c_{j} p_{j}(x)+\sum_{i=1}^{n} \lambda_{i} \varphi\left(r\left(x, x_{i}\right)\right)
$$

where $m$ is the number of the polynomial terms, $c_{j}$ is the coefficient for polynomial basis function $\mathrm{p}_{\mathrm{j}}(\mathrm{x})$ and $\mathrm{n}$ is the number of sample points. $\lambda_{i}$ is the weighted coefficient for the term for the $\mathrm{i}$-th variable, $\mathrm{r}\left(\mathrm{x}, \mathrm{x}_{\mathrm{i}}\right)$ is the Euclidean distance expressed in terms of $\left\|x-x_{i}\right\|$ and $\varphi(r)$ is the radial basis function.

\subsection{Kriging model}

In recent years, the Kriging method has found wider application as a spatial prediction method in engineering design. The basic postulate of this formulation, given by Simpson [12], is:

$$
y(x)=f(x)+Z(x) .
$$

where $y(x)$ is the unknown function of interest, $f(x)$ models the global trend of the function of interest and $\mathrm{Z}(\mathrm{x})$ models the correlation between the points by a stochastic process whose mean is zero and variance is $\sigma^{2} . \mathrm{Z}(\mathrm{x})$ provides local deviations and the covariance between different points is modelled as:

$$
\operatorname{Cov}\left(Z\left(x_{i}\right), Z\left(x_{j}\right)\right)=\sigma^{2} \bar{R}\left(\left[R\left(x_{i}, x_{j}\right)\right]\right) .
$$

With $\mathrm{L}$ the number of sampling points, $\overline{\mathrm{R}}$ is the $\mathrm{LxL}$ correlation matrix defined by Gaussian correlation function $\mathrm{R}\left(\mathrm{x}_{\mathrm{i}}, \mathrm{x}_{\mathrm{j}}\right)$ as follows:

$$
R\left(x_{i}, x_{j}\right)=\prod_{k=1}^{n} \exp \left[-\theta_{k}\left(x_{i}^{k}-x_{j}^{k}\right)^{2}\right] .
$$

where $\mathrm{n}$ is the number of variables, $\theta_{\mathrm{k}}$ is the unknown correlation parameter to determine and $\mathrm{x}_{\mathrm{i}}{ }^{\mathrm{k}}$ is the $\mathrm{k}$-th component of sample point $\mathrm{x}_{\mathrm{i}}$.

\subsection{Successive response surface method}

When performing a surrogate-based optimization, a basic assumption is that the surrogate model is sufficiently accurate and it is only necessary to find the optimum design using the established surrogate model [13]. However the surrogate model obtained using initial samples will probably not be accurate in the local region of the final optimum. It is common to exploit this local region by sequentially positioning additional samples inside. On the other hand, exploring design space is a strategy to increase the global accuracy of a surrogate model. Considering both exploitation and exploration, successive response surface method (SRSM) [14] has been proposed, in which the region of interest (RoI) is gradually shrunk to a smaller area around the optimum by panning and zooming within the design space during the iterations (Figure 1). In the successive surrogate modeling method, the center of RoI at the $(\mathrm{k}+1)$-th iteration is the optimum $\mathrm{x}^{(\mathrm{k})^{*}}$ of the $\mathrm{k}$-th iteration and its size is a fraction of the size of the $\mathrm{k}$-th iteration, calculated using the distance between the optimum and the center of the current RoI.

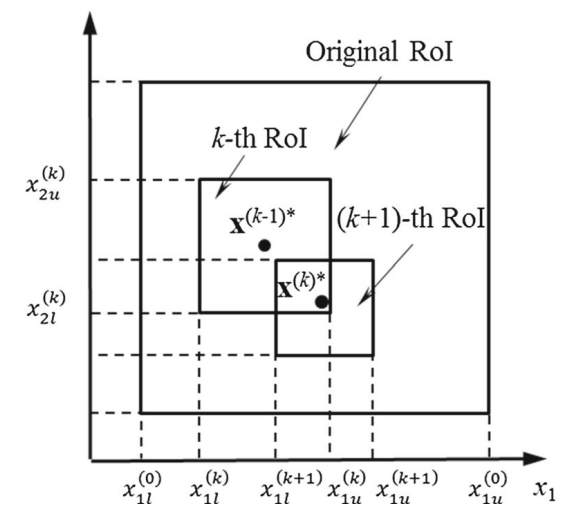

Figure 1. Updating process of Rol [3]

While SRSM has been demonstrated to be able to identify the optimum region for various crashworthiness problems [14-16], iterative resampling might be prohibited in practice as crashworthiness simulations are 
rather expensive computationally. Implementation of Latin hypercube design [17], which is a technique to inherit previous sample points, might help reduce the required number of sample points in subsequent iterations.

\section{STRUCTURAL OPTIMIZATION}

The model of an impact attenuator in composite material subjected to axial dynamic loading [18-20] was provided to obtain the optimum solution comparing the two different surrogates. LS-OPT was used to build the respective metamodels, while LS-DYNA solver [21-24] was implemented to conduct the explicit crash simulations.

In general, a problem of crashworthiness optimization can be formulated mathematically as:

$$
\left\{\begin{array}{l}
\min (\text { or } \max ) f(x) \\
\text { s.t. } g(x) \leq 0 \\
\quad x_{L} \leq x \leq x_{U}
\end{array}\right.
$$

where $f(x)$ and $g(x)$ are the objective and constraint vectors, respectively and $\mathrm{x}$ denotes the vector of design variables.

In this study, the optimization goal is the maximum response of the specific energy absorption (SEA) constrained with the conditions of the maximum acceleration, average acceleration, maximum stroke in order to satisfy the requirements imposed by rules [21] and maintain a controlled and progressive deformation. Therefore, the mathematical model for the structural optimization is as follows:

$$
\begin{aligned}
& \max S E A(t, t 2, t 3) \\
& \text { subject to }\left\{\begin{array}{l}
\text { Max_acceleration }<65 \mathrm{~g} \\
\text { Average_acceleration }<20 \mathrm{~g} \\
\text { Max_stroke }<130 \mathrm{~mm} \\
15 \mathrm{~g}<\text { Average_acc_1<25g (between } 2 \text { and } 5 \mathrm{~ms} \text { ) } \\
15 \mathrm{~g}<\text { Average_acc_2<25g (between } 5 \text { and } 15 \mathrm{~ms} \text { ) } \\
15 \mathrm{~g}<\text { Average_acc_3<25g (between } 15 \text { and } 30 \mathrm{~ms} \text { ) } \\
1.2 \leq \mathrm{t} \leq 2 \\
1.5 \leq \mathrm{t} 2 \leq 2.5 \\
2 \leq \mathrm{t} 3 \leq 3
\end{array}\right.
\end{aligned}
$$

In such case the design variables are the three thickness of each zone ( $\mathrm{t}, \mathrm{t} 2$ and $\mathrm{t} 3$ respectively), as shown in Figure 1, parametrized directly in the LS-DYNA input file.

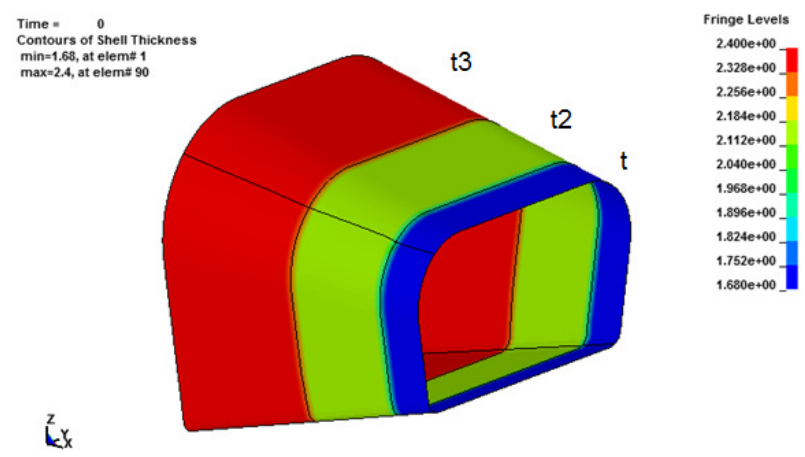

Figure 2. Impact attenuator configuration at the beginning

To compare different interpolation techniques, it is possible to examine the difference between the obtained data and the predicted one using the root mean squared error (RMSE), maximum residual error $\left(\varepsilon_{\max }\right)$ and coefficient of determination $\left(\mathrm{R}^{2}\right)$. The first one is computed for each function as follows:

$$
R M S E=\sqrt{\sum_{i=1}^{P} \frac{1}{P}\left(\bar{y}_{i}-y_{i}\right)^{2}}
$$

where $\mathrm{P}$ is the number of checkpoints, $\mathrm{y}_{\mathrm{i}}$ is the function value at the point and $\bar{y}_{i}$ is the predicted value using metamodel. Maximum residual error is the maximum value of the difference between the observed and predicted response. The coefficient of determination is evaluated as:

$$
R^{2}=\frac{\sum_{i=1}^{P}\left(\bar{y}_{i}-\hat{y}\right)^{2}}{\sum_{i=1}^{P}\left(y_{i}-\hat{y}\right)^{2}}
$$

where hat symbol means the average value of the $y_{i}$ results.

\section{RESULTS AND DISCUSSION}

Table 1 shows the optimal values of the thicknesses for Radial and Kriging metamodels, respectively. It is evident how different surrogates give feasible and very comparable solutions. In both cases, no great variation in term of values can be noted between the second and the third zone; therefore, the repartition of the structure into three parts seems to be not necessary given the inclination of the shells in the longitudinal direction. Only a smaller thickness must be guaranteed into the first part of the attenuator, to reduce the peak load and undergo a progressive and controlled deformation.

Table 1. Variables optimal values for both surrogates

\begin{tabular}{|l|c|c|c|}
\hline \multirow{2}{*}{ Metamodel } & \multicolumn{3}{|c|}{ Design variables } \\
\cline { 2 - 4 } & $\mathrm{t}$ & $\mathrm{t} 2$ & $\mathrm{t} 3$ \\
\hline RBF & 1.21 & 2.06 & 2.10 \\
\hline Kriging & 1.27 & 2.06 & 2.06 \\
\hline
\end{tabular}

In terms of objective and constraints values it is possible to note how both metamodels are able to improve the base configuration (Table 2).

Table 2. Optimum results of RBF and Kriging metamodel

\begin{tabular}{|l|c|c|c|}
\hline & Base & RBF & Kriging \\
\hline SEA (kJ/kg) & 14.91 & 16.90 & 16.99 \\
\hline Max_acc $(\mathrm{g})$ & 77.28 & 57.92 & 61.58 \\
\hline Average_acc $(\mathrm{g})$ & 15.79 & 15.64 & 15.45 \\
\hline Max_stroke $(\mathrm{mm})$ & 101.8 & 126.5 & 127.6 \\
\hline
\end{tabular}

The accuracy of these models can be assessed using statistical methods [25]. Therefore, the deviation of predicted response from the actual value is evaluated by RMS Error, maximum residual and $\mathrm{R}^{2}$ values respectively of the checkpoints for both configurations (Table 3). This values must be small enough, except for $\mathrm{R}^{2}$ where a value near to unit should be obtained, to accept the accuracy of predicted to calculated values. Both for objective and constraints, the Kriging method presents the best results for each criterion. 
Table 3. Accuracy for objective and constraints

\begin{tabular}{|l|c|c|c|c|c|c|}
\hline & \multicolumn{3}{|c|}{ RBF } & \multicolumn{3}{c|}{ Kriging } \\
\hline & RMSE(\%) & $\varepsilon_{\max }$ & $\mathrm{R}^{2}$ & $\mathrm{RMSE}(\%)$ & $\varepsilon_{\max }$ & $\mathrm{R}^{2}$ \\
\hline SEA & 0.01 & 0.01 & 1 & $1 \mathrm{e}-11$ & $1 \mathrm{e}-11$ & 1 \\
\hline Max_acc & 1.6 & 0.05 & 0.97 & $3 \mathrm{e}-10$ & $8 \mathrm{e}-12$ & 1 \\
\hline Average_acc & 2.8 & 0.01 & 0.54 & $4 \mathrm{e}-9$ & $3 \mathrm{e}-11$ & 1 \\
\hline Max_stroke & 6.5 & 22.8 & 0.72 & $1 \mathrm{e}-8$ & $9 \mathrm{e}-8$ & 1 \\
\hline Av_acc_1 & 4.7 & 0.02 & 0.89 & $1 \mathrm{e}-8$ & $1 \mathrm{e}-10$ & 1 \\
\hline Av_acc_2 & 4.5 & 0.03 & 0.79 & $2 \mathrm{e}-8$ & $3 \mathrm{e}-10$ & 1 \\
\hline Av_acc_3 & 8.6 & 0.04 & 0.74 & $9 \mathrm{e}-9$ & $1 \mathrm{e}-10$ & 1 \\
\hline
\end{tabular}

As the Kriging metamodel, for such crashworthiness analysis, presents better behaviour than the RBF one, from now on, only the Kriging results will be displayed. Figure 3 shows the optimization history for variables and objective varying iteration step. It is evident how the domain of each thickness tends to reduce in time up to converge to the optimal solution. Moreover also the SEA value tends to stabilize around a value of about $17 \mathrm{~kJ} / \mathrm{kg}$.

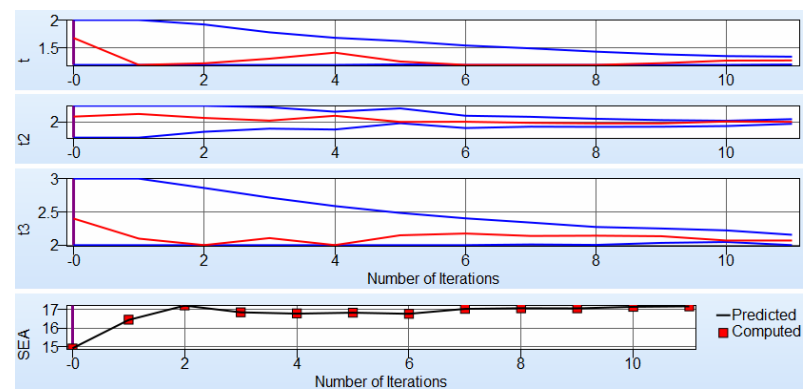

Figure 3. Optimization history for variables and objective

Sensitivity analysis allows to determine the significance of the design variables. In LS-OPT two sensitivity measures are implemented: Linear ANOVA (Figure 4) and GSA/Sobol (Figure 5). ANOVA depicts positive or negative influence, while Sobol just shows the normalized absolute value. It is evident how the $\mathrm{t} 3$ variable, that depicts the thickness of the last zone of the attenuator, is the most influential in terms of SEA, followed by $\mathrm{t} 2$ and $\mathrm{t}$. The same trend can be also observed in terms of maximum stroke and average acceleration. Only for maximum acceleration an opposite trend is shown; in such case the first thickness of the structure under impact has the greatest relevance. This is obvious because the maximum acceleration is reached in the first time intervals, when the attenuator comes into contact with the rigid wall.

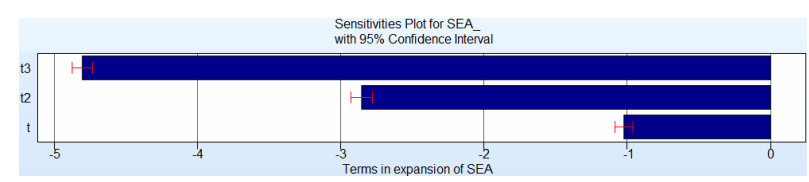

Figure 4. ANOVA values for the objective

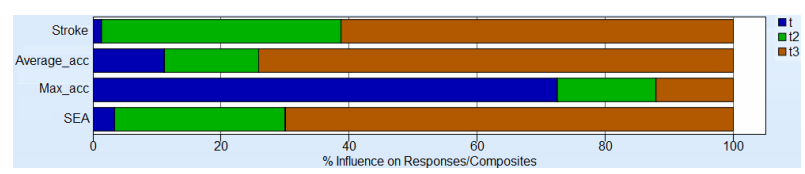

Figure 5. Sobol values for multiple responses

The three dimensional response surfaces obtained from the Kriging model and simulation points were plotted for the average acceleration constraint vs. design variables (Figure 6). The quadratic trend is able to capture minimum and maximum points.

The diagram of deceleration vs. displacement for the base and optimized configuration is illustrated in Figure 7. For the optimized solution, it is evident a more constant acceleration, a lower peak and a more extensive deformation respect to the base geometry. The new configuration guarantees a mass reduction of about $12 \%$, a specific energy absorption greater than about $14 \%$ respect to the original FE simulated model. Figure 8 shows the progressive deformation of the optimized impact attenuator in time.

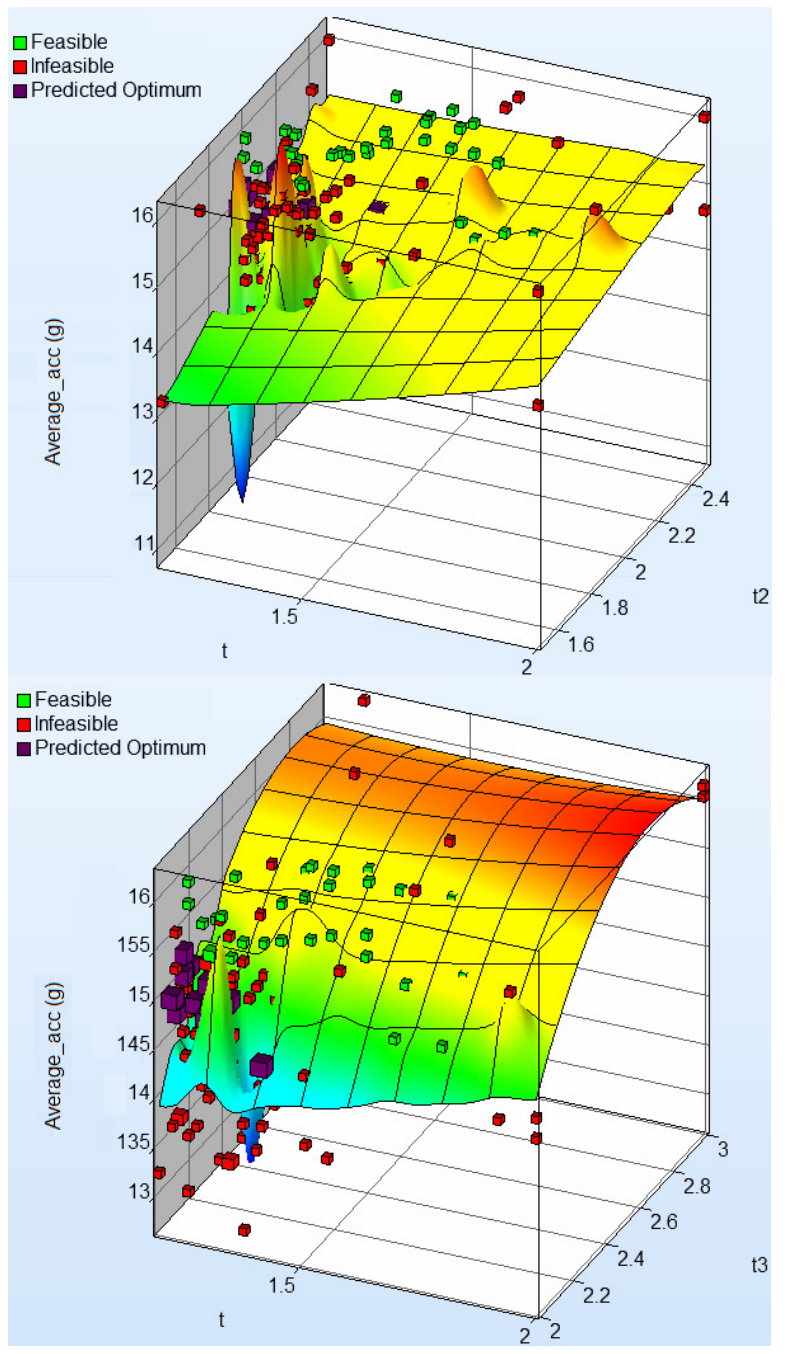

Figure 6. Response surfaces for the average acceleration

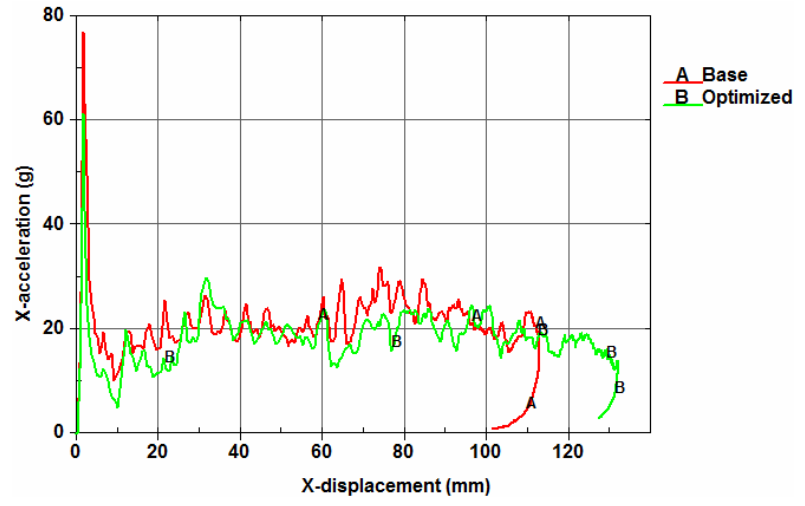

Figure 7. Acceleration vs. displacement for base and optimized configuration 


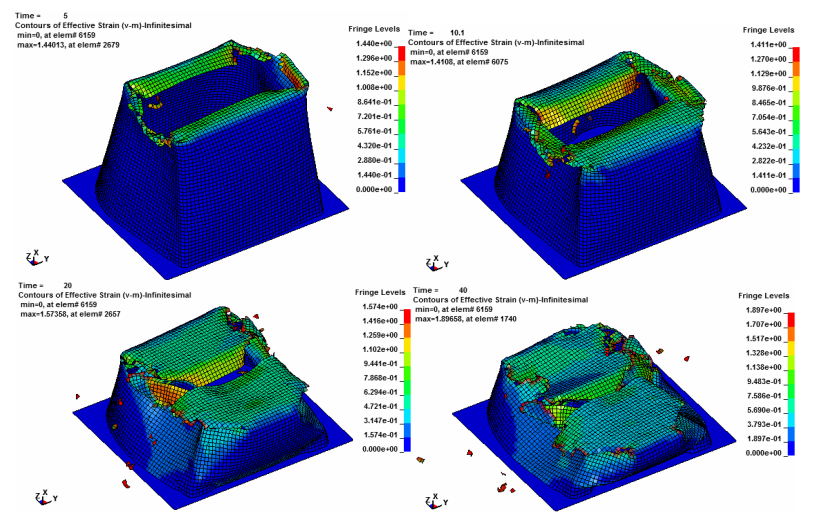

Figure 8. Deformation of the impact attenuator in time

\section{CONCLUSION}

In this study, single objective design optimization of a composite impact attenuator was conducted using the RBF and Kriging metamodels. The numerical models were simulated by LS-DYNA finite element code and coupled with surrogates through LS-OPT. The accuracy of the results was assessed using statistical techniques. Finally, a successful implementation of such optimization by RBF and Kriging methods demonstrated that the crushing performance in term of specific energy absorption of the impact attenuator improved by $13 \%$ and $14 \%$, respectively. From the statistical methods it is evident how the Kriging method has a better capacity to determine the optimum solution respect to the Radial one, even if no great differences can be observed from the point of view of the design variables values.

\section{REFERENCES}

[1] Pavlovic, A., Zivkovic, M.: Roll cage design and validation for a rally vehicle, FME Transactions, Vol. 44, No. 4, pp. 398-404, 2016.

[2] Garinis D., Dinulovic M, Rašuo B.: Dynamic Analysis of Modified Composite Helicopter Blade, FME Transactions, Vol. 40 No 2, 2012, pp 63-68.

[3] Rasuo, B.: Experimental Techniques for Evaluation of Fatigue Characteristics of Laminated Constructions from Composite Materials: FullScale Testing of the Helicopter Rotor Blades, Journal of Testing and Evaluation (JTE), Volume 39, Issue 2 (March 2011), ASTM International, USA, pp. 237-242.

[4] Vujovic, A., Krivokapic, Z., Grujicic, R., Jovanovic, J., Pavlovic, A.: Combining FEM and neural networking in the design of optimization of traditional montenegrin chair, FME Transactions, Vol. 44, No. 4, pp. 374-379, 2016.

[5] Tanaskovic, J.D. et al., Experimental and numerical determination of tube collision energy absorbers characteristics, FME Transactions, Vol. 40, No. 1, pp. 11-16, 2012.

[6] Beaumont P.W.R., Soutis C. and Hodzic A. (Editors): Structural integrity and durability of advanced composites: Innovative modelling methods and intelligent design, Woodhead Publishing - Elsevier, Cambridge, UK, 2015.
[7] Zeng, D., Duddeck, F.: Improved hybrid cellular automata for crashworthiness optimization of thinwalled structures, Structural and Multidisciplinary Optimization, pp. 1-15, 2017.

[8] Duddeck, F. et al.: Topology optimization for crashworthiness of thin-walled structures under axial impact using hybrid cellular automata, Structural and Multidisciplinary Optimization, Vol. 54, pp. 415-428, 2016.

[9] Rasuo, B.: An Experimental Methodology for Evaluating Survivability of an Aeronautical Constructions from Composite Materials: An Overview, International Journal of Crashworthiness, Volume 12, Issue 1, Taylor \& Francis, London, 2007, pp. 9-15.

[10]Fang, J., Sun G., Qiu, N., Kim, H.N., Li, Q.: On design optimization for structural crashworthiness and its state of the art, Structural and Multidisciplinary Optimization, pp. 1-29, 2016.

[11] Hardy, R.L.: Multiquadric equations of topography and other irregular surfaces, Journal of Geophysical Research, Vol. 76, No. 8, pp. 1905-1915, 1971.

[12] Simpson, T.W.: A Concept Exploration Method for Product Family Design, PhD thesis, Georgia Institute of Technology, 1998.

[13] Forrester, A., Keane, A.J.: Recent advances in surrogate-based optimization, Progress in Aerospace Sciences, Vol. 45, No. 1-3, pp. 50-79, 2009.

[14] Kurtaran, H. et al.: Crashworthiness design optimization using successive response surface approximations, Computational Mechanics, Vol. 29, No. 4, pp.409-421, 2002.

[15] Stander, N., Craig, K.J.: On the robustness of a simple domain reduction scheme for simulationbased optimization, Engineering Computations, Vol. 19, No. 4, pp. 431-450, 2002.

[16] Liu, S.-T., Tong, Z.-Q., Tang, Z.-L., Zhang, Z.-H.: Design optimization of the $S$-frame to improve crashworthiness, Acta Mechanica Sinica, Vol. 30, No. 4, pp. 589-599, 2014.

[17] Wang, G.G.: Adaptive response surface method using inherited latin hypercube design points, Journal of Mechanical Design, Vol. 125, No. 2, pp. 210-220, 2003.

[18] Obradovic, J. et al.: Lightweight design and crash analysis of composite frontal impact energy absorbing structures, Composite Structures, Vol. 94, No. 2, pp. 423-430, 2012.

[19]Boria, S., Obradovic, J., Belingardi, G.: Experimental and numerical investigations of the impact behaviour of composite frontal crash structures, Composites Part B, Vol. 79, pp. 20-27, 2015.

[20] Belingardi, G., Boria, S., Obradovic, J.: Energy absorbing sacrificial structures made of composite materials for vehicle crash design, in: Abrate S. et al. (Ed.): Dynamic Failure of Composite and Sandwich Structures, Solid Mechanicsa and Its Applications, Springer, Vol. 192, pp. 577-609, 2013. 
[21] Hallquist, J.O.: LS-DYNA Users Manual Version 971, Livermore Software Technology Corporation, Livermore, 2007.

[22] Pavlovic, A., and C. Fragassa. Numerical modelling of ballistic impacts on flexible protection curtains used as safety protection in woodworking, Proceedings of the Institution of Mechanical Engineers, Part C: Journal of Mechanical Engineering Science, Vol. 231., No.1, pp: 44-58, 2017.

[23] Pavlovic, A. et al.: Comparative numerical and experimental study of projectile impact on reinforced concrete, Composites Part B: Engineering, Vol. 108, pp. 122-130, 2017.

[24]SAE, 2015 Formula SAE Rules, Society of Automotive Engineers, 2014.

[25] Esfahlani, S.S., Shirvani, H., Nwaubani, S., Shirvani, A., Mebrahtu, H.: Comparative study of honeycomb optimization using Kriging and radial basis function, Theoretical \& Applied Mechanics Letters, Vol. 3, 2013.

\section{ОПТИМИЗАЦИЈА УДАРА КОМПОЗИТНОГ ПРИГУШИВАЧА ПОД УТИЦАЈЕМ ДИНАМИЧКОГ АКСИЈАЛНОГ ЛОМА}

\section{С. Бориа, Ј. Обрадовић, Г. Белингарди}

Моторизација доноси два велика изазова савременом друштву. Прво, безбедност путева и возила постаје све значајнија, што је посебно појачало законодавне услове за увођење ефикасније заштите система на возилу. Друго, постоји све већи проблем у окружењу и одрживости, што у великој мери гура стандарде ка смањењу потрошње горива. Из тих разлога, аутомобилска индустрија је посветила значајан напор да испоручи више возила отпотних на удар ради истовременог решавања ова два питања. Током протекле две деценије оптимизација конструкција је развијена као моћно средство за претрагу возила која су најотпорнија на удар са најлакшом могућом структуром за различита возила, стога отпимизација постаје важна тема истраживања. У оптимизацији отпора на удар, директна метода може бити неефикасна, јер итеративна нелинеарна FEA метода током оптимизације обично захтева велике рачунарске напоре и доводи до високог ризика од превременог неуспеха симулације пре коректне конвергенције. Као резултат тога, сурогатни модели (или метамодели) се све чешће користе као алтернатива за формулисање пројектантних критеријума у погледу експлицитних променљивих функција дизајна у унапредој оптимизацији, који је доказано ефикасан и понекад јединствен приступ. Идеја сурогат моделирања је да изгради приближно функцију на основу низа процена различитих узорака, у коме је дизајн обично примерак коришћења елспериемнталне методе. Затим, FEA метода је примењен на ове узорке да би се успоставио сурогат модел са одређеном апроксимацијом за оптимизацију возила у ситуацији урада.

Овај рад даје резултате добијене из процедуре оптимизације композитног пригушивача на удар под утицајем динамичког аксијалног удара, користећи два различита метамодела, као што су Радиална Основна функција и Кригинг. Оптимизација димензија за неке геометријске параметре је решена комбинацијом комерцијалних солвера LS-DYNA са оптимизатором LS-OPT. Да би се измерила погодност резултата и упоредили различите сурогатне моделе, коришћени су глобални параметри грешака, као што је корен средње квардатне грешке, максимална преостала грешка и коефицијент одређивања. 